\title{
VASCULAR PLANTS DISTRIBUTION AS A TOOL FOR ADAPTIVE FOREST MANAGEMENT OF FLOODPLAIN FORESTS IN THE DYJE RIVER BASIN
}

\author{
PETR MADĚRA ${ }^{1)}$, JAN ŠEBESTA ${ }^{1)}$, RADOMÍR ŘEPKA ${ }^{1)}$, MARTIN KLIMÁNEK ${ }^{2)}$ \\ 1) Department of Forest Botany, Dendrology and Geobiocoenology, Mendel University in \\ Brno, Czech Republic, Zemédělská 1, 61300 Brno,petrmad@mendelu.cz \\ 2) Department of Geoinformation Technologies, Mendel University in Brno, Czech \\ Republic, Zemédělská 1, 61300 Brno
}

Received: $25^{\text {th }}$ February 2011, Accepted: $5^{\text {th }}$ July 2011

\begin{abstract}
The study is based on a full floristic inventory of floodplain forests in South Moravia along the upper part of the Dyje River (Forest district Valtice). The study area is located in the Dolní Morava Biosphere Reserve and includes several Sites of Community Importance within Natura 2000. The aim of the inventory was to analyze diversity of herb and woody species occuring in the study area, including both native protected and threatened species, and invasive species. The study area was divided into segments. A segment represented the smallest unit of spatial forest division - "forest stand part". The species were recorded into a special scratch-list. Altogether, 656 plant species were found. The floristic database has been integrated with GIS. Maps of distribution of selected plant species or groups of plants were produced. On the basis of geographical visualization of the above mentioned results we identified areas with a high diversity of all species and endangered species. The results may be used as a base for adaptive forest and environmental management.
\end{abstract}

\section{INTRODUCTION}

Alluvial areas, ecotones between terrestrial and aquatic ecosystems belong to the most dynamic and productive ecological systems. They perform many valuable functions in the landscape (Naiman and DeCamps 1997; Naiman et al. 1993, 2005; Verry et al. 2000). Alluvial areas are often hotspots of biodiversity: species richness of certain organisms, such as vascular plants, often far exceeds that of the adjacent upland habitats (Naiman et al. 1993, 2005; Stohlgren et al. 1998). The high biodiversity based on high variability of site conditions is typical for floodplain forests (Hager, Klimo 2001). The important ecological functions of alluvial areas, and their value in biodiversity conservation, have made alluvial landscape conservation and restoration a high priority for ecosystem managers in many countries (Naiman et al. 2005; Verry et al. 2000).

Riparian ecosystems are important elements in landscapes that often provide a disproportionately wide range of ecosystem services and conservation benefits (Jones et al. 2010). From nature conservation point of view it is especially the ability to fill the considerable ecostabilizing and corridor functions for biodiversity maintenance in the 
riverine landscape (Maděra et. al 2004). Mature and diverse floodplain forests are among the world's most diminished ecosystems and conservationists are in need of a method to identify the best remaining examples of these systems (Anderson, 2010).

The nutrient-rich floodplain soil forms a prime medium for agriculture and forestry, the practice of which has led to extensive flood regulation and the direct loss of the natural habitat. In the northeast of the USA, floodplains are among the most converted and least protected settings in the region, and, globally, temperate rivers and their floodplain wetlands are among the most threatened ecosystems (Dynesius and Nilsson 1994). Similarly in Central Europe, due to the long-term and intensive anthropogenic effects in floodplains (Wenger et al., 1990), large numbers of extensive tracts of floodplain forests have been destroyed.

The aim of the study is to collect and evaluate data on diversity and distribution of vascular plants in the study area as a basis for the assesment of principles of adaptive management.

\section{MATERIAL AND METHODS}

\section{Study area}

Floodplain forests of the Dyje-Morava alluvium in the Czech Republic rank with the most preserved and most extensive regions of floodplain communities in Central Europe. The man-made natural forests are prevailing, however, they were affected by changes in the hydrological regime caused by complex hydrotechnical measures of the south-moravian region in the seventies (Penka et al. 1991). This, one of the largest coherent forest complex in Central Europe, serves as an important instrument for sustainable development of the area based on the following three pillars (Tab.1).

Table 1: Three pillars of floodplain forest management for sustainable development in region

\begin{tabular}{|l|l|l|}
\hline Economical pillar & Social and cultural pillar & Ecological and environmental pillar \\
\hline $\begin{array}{l}\text { High production } \\
\text { capacity of valuable } \\
\text { timber }\end{array}$ & $\begin{array}{l}\text { Longterm history of } \\
\text { landscape settlement and } \\
\text { landuse }\end{array}$ & High proportion of close-natural forest \\
\hline $\begin{array}{l}\text { Biggest game park in } \\
\text { the CR }\end{array}$ & Longterm hunting history & $\begin{array}{l}\text { Habitat for endangered fauna, } \\
\text { especially for xylophagous beatles, } \\
\text { water birds, amphibians and fis }\end{array}$ \\
\hline Employment in region & $\begin{array}{l}\text { Creation of landscape } \\
\text { character }\end{array}$ & Habitat for endangered flora \\
\hline $\begin{array}{l}\text { Protection against } \\
\text { floods }\end{array}$ & \multicolumn{2}{|l}{} \\
\hline
\end{tabular}

History of forest management in the study area (Nožička, 1956) is crucial for understanding of the current state. Alluvia of the Dyje and the Morava rivers have been continuously inhabited since the Stone Age. Famous archeological locations from the times of mammoth hunters to the Slavonian age were found there. In the Middle Ages, coppice forests with 7year rotation are described and coppices with standard are documented, too. The forests were used for livestock grazing (especially pigs) due to acorn production. The "modern forest management" began under the Lichtenstein family ownership in the middle 
of the18th century. The conversion of coppice forest to high forest started by using the way of alternate forestry (agroforestry) system. In 1945, the Lichtenstein ownership was nationalized by the former Czechoslovak Republic and an intensive socialist management was started. The area was behind the Iron-curtain due to its location near the Austrian border. It was the reason why the near-natural forests were not replaced by poplar plantations and the area preserved its high biological value. After the „Velvet revolution“ (1989) in the Czech Republic,scientists gradually discovered the significance of the area from the nature conservation point of view. This was mainly due to the occurence of vascular plants, Vicherek et al. (2000). Nature protection pays increased attention to this area, a small part of the study area belongs to the Pálava Landscape Protected Area, a few small-scale nature reserves were declared in the area of study and important sites of NATURA 2000 are also located there. The study area belongs to the Lower Morava Biosphere reserve of UNESCO. On the other hand, the floodplain forests in the Dyje river alluvium, as highly productive forests, are managed by the Židlochovice Forest Enterprise. The subject of this study was the Valtice forest district with area of 1,600 ha.

\section{METHODS}

All vascular plants were recorded up to the level of segments within the study area; each segment corresponds with one stand part, i.e. the smallest unit of spatial division of forest. In each segment the presence of species was marked on a scratch-list which contained 263 most common herb species of South Moravian floodplain forests. More rare herb species and woody plants were then added to the list. Species present only on the edge of the particular segment are marked separately (stand in contact with a forest road, water channel, forest aisle, meadow) and so are dominant species (with the cover of $40 \%$ or more). A record is the presence of one species in one segment. Scratch-lists were transferred into databases and served for further elaboration. A segment becomes a locality once it was digitalized (a point in a map). GIS environment (ArcGIS) was used for digitalization and elaboration of species distribution maps.

\section{RESUlTS}

\section{Importance of the area from the biodiversity point of view}

Based on field surveys we found the total of 656 species of vascular plants (563 herbs and 93 woody plants ) in 38,890 records, however, 170 of them were adventive species (according to Pyšek et al. 2002) in 6,822 records, 102 archaeophytes (4,151 records) and 68 neophytes $(2,671$ records). On the other hand, 110 endangered species were determined in 2,869 records acording to the Red list of vascular plants of the Czech Republic (Holub, Procházka 2000), out of which 24 species are protected by the Czech law. The results show the enormous significance of the study area for biodiversity conservation but also highlight the problem of adventive species expansion ( $26 \%$ of species, $17.5 \%$ of records). 
Table 2: Occurence of adventive species in the study area

\begin{tabular}{|c|c|c|c|c|c|c|c|c|}
\hline \multicolumn{5}{|c|}{ Number of adventive species } & \multicolumn{4}{c|}{ Records number of adventive species } \\
\hline & Total & Casual & Invasive & Naturalized & Total & Casual & Invasive & Naturalized \\
\hline Archaeophytes & 102 & 7 & 13 & 82 & 4151 & 30 & 1030 & 3091 \\
\hline Neophytes & 68 & 12 & 36 & 20 & 2671 & 122 & 1783 & 766 \\
\hline Total adventive & 170 & 19 & 49 & 102 & 6822 & 152 & 2813 & 3857 \\
\hline
\end{tabular}

Table 3: Occurence of endangered species in the study area

\begin{tabular}{|c|c|c|}
\hline Threat category & Records No. & Species No. \\
\hline $\mathrm{C} 1$ & 90 & 5 \\
\hline $\mathrm{C} 2$ & 494 & 31 \\
\hline $\mathrm{C} 3$ & 490 & 29 \\
\hline $\mathrm{C} 4$ & 1795 & 45 \\
\hline$\S 1$ & 125 & 5 \\
\hline$\S 2$ & 51 & 13 \\
\hline$\S 3$ & 29 & 6 \\
\hline
\end{tabular}

When considering indigenousness, the fact is that 170 recorded plant species belong to various categories of adventive species (Tab.2) out of which are 102 species archeophytic and 68 neophytic; 49 species are invasive. Only Cirsium arvense in $72 \%$ of segments, Tanacetum vulgare (44\% segments), Tripleurospermum inodorum (31\% segments), Viola odorata (31\% segments) and Cirsium vulgare (21\% segments) are invasive archeophytes of higher importance whereas only the first of them tends to become dominant on woodland edges and clearings. The most important invasive neophyte is without a doubt a highly aggressive species of the area, Aster lanceolatus, which is present in more than $69 \%$ of segments and often dominant in younger and older stands of floodplain forest causing nowadays a nearly irresolvable problem (̌̌epka, Maděra 2009a). Also other invasive species, like Impatiens parviflora, Bidens frondosa, Conyza canadensis, Acer negundo and Impatiens glandulifera are abundant in the area and tend to penetrate woodland communities.

Should we concentrate on endagered and protected species, there are 110 plant species (Tab.3) in this area whereas 24 species are protected by law with the total number of 205 records in segments. The biotope of floodplain forests is of a great importance for species like Leucojum aestivum (14\% segments), Euphorbia palustris (2\%) and E.lucida (8\%), Carex divulsa (34,5\%), Cardamine dentata (2\%), Carex strigosa (1\%) or Carex riparia $(82 \%)$. Other species indicating heavy soils with variable moisture or soils subhalophylous have the centre of occurrence on alluvial meadows and only occur on woodland edges or clearings - they are for example Viola elatior, Scutellaria hastifolia, Carex melanostachya, Teucrium scordium, Lathyrus palustris, Dipsacus laciniatus, Leonurus marubiastrum, Lycopus exaltatus, Sonchus palustris, Lythrum virgatum, Cnidium dubium, Silaum silaus, Inula salicina. Wetlands, water canals and their edges are important biotopes for species like Juncus atratus, Hottonia palustris, Butomus umbellatus, Cardamine matthioli, Leersia oryzoides, Scrophularia umbrosa, Veronica scutellata or Carex buekii. Raised sandy fluvial 
deposits, called "hrudy", host for example Scilla drunensis, Galanthus nivalis, Hesperis sylvestris. The floodplain forests are important habitat for endangered woody plants too, for example Malus sylvetstris, Pyrus pyraster, Ulmus minor and U.laevis or Populus nigra.

\section{Centers of biodiversity}

Map 1 shows the distribution of segments (stand parts) according to biodiversity level. They help to distinguish the most valuable areas from the biodiversity point of view.

\section{Map 1: Number of all vascular plant species per segment}

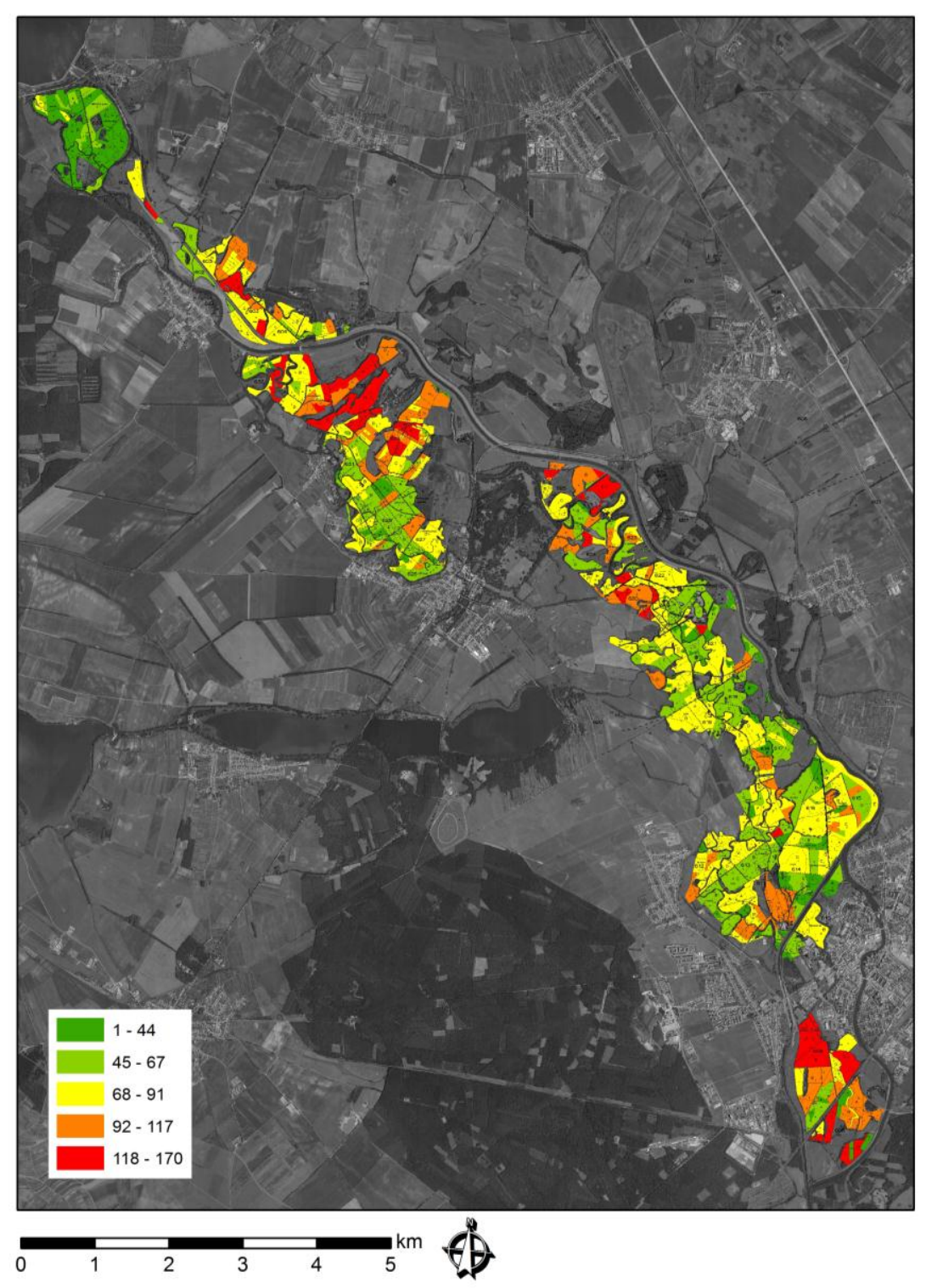




\section{Endangered species distribution}

The knowledge of endangered species distribution (maps 2 and 3) is very important for forest managers and nature protection authorities. They can directly adjust their silvicultural and forest restoration measures.

Map 2: Number of all endangered vascular plant species per segment according to Holub, Procházka (2000)

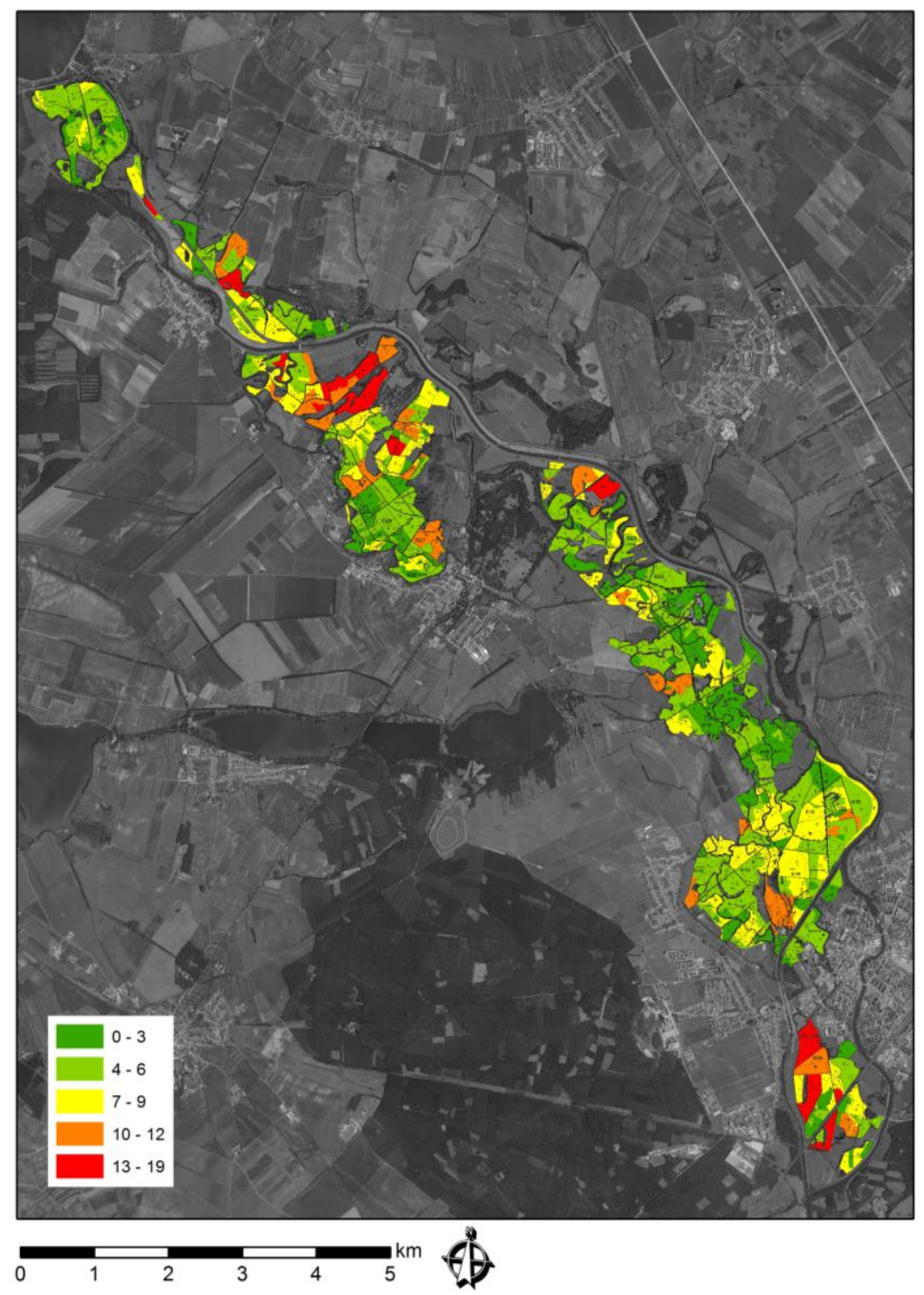


Map 3: Number of critical (C1) and strong (C2) endangered vascular plant species per segment according to Holub, Procházka (2000)

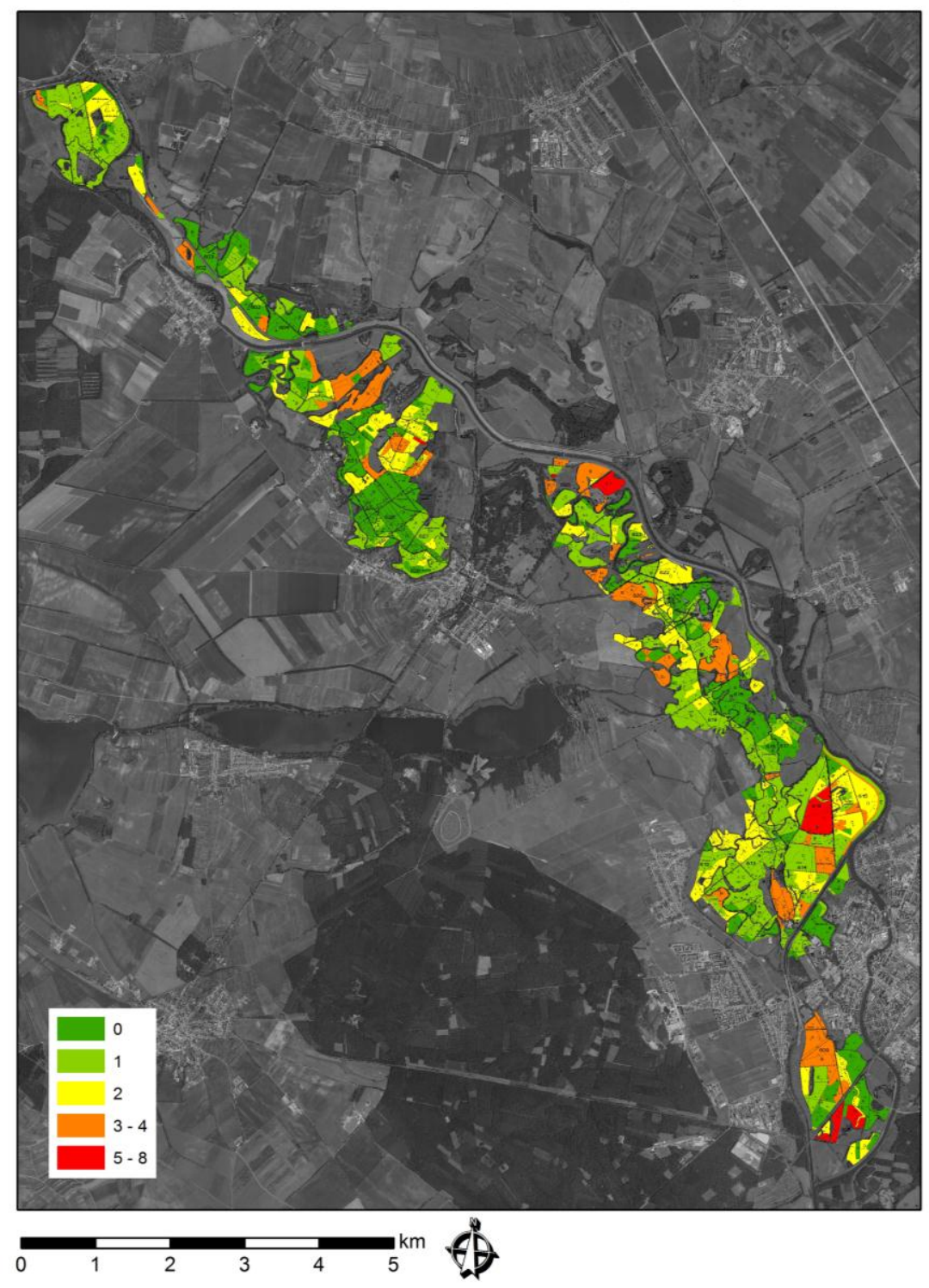

\section{Importance of developmental stages of forest stands}

Forestry in the study area has longterm used clear cuttings system for forest restoration especially by oak as a light demanding tree species. This system was used by conversion of low forest form to high forest form more than two hundred years ago. Agricultural crops (corn, potatoes) were planted among rows of young trees in those times. 
We determined group of herbs with high fidelity to clearings - 69 species $(12.3 \%$ of all herbs) occured in clearings in more than $50 \%$ records, 14 of them (14.3\% of all endangered species) belong to endangered (Tab. 4).

Table 4: Occurence of herbs in clearings and forest interior

\begin{tabular}{|c|c|c|c|c|}
\hline $\begin{array}{c}\text { Fidelity to } \\
\text { clearings }\end{array}$ & $\begin{array}{c}\text { Total No. } \\
\text { of species }\end{array}$ & $\begin{array}{c}\text { No of endangered } \\
\text { species }\end{array}$ & $\begin{array}{c}\text { No of adventive } \\
\text { species }\end{array}$ & $\begin{array}{c}\text { Fidelity to } \\
\text { forest interior }\end{array}$ \\
\hline $100 \%$ & 27 & 5 & 8 & $0.0 \%$ \\
$75-99 \%$ & 4 & 1 & 2 & $0.1-24 \%$ \\
$50-74 \%$ & 38 & 8 & 18 & $25-49 \%$ \\
$25-49 \%$ & 98 & 11 & 38 & $50-74 \%$ \\
$0.1-24 \%$ & 222 & 25 & 32 & $75-99 \%$ \\
$0 \%$ & 179 & 48 & 46 & $100 \%$ \\
\hline
\end{tabular}

\section{Importance of forest edges}

Forest edges serve not only as an important habitat for some herb species but also as corridors for their dispersion. According to Table 5, 58 herb species show high fidelity (occurence in more than $50 \%$ of records) to habitats of forest edges (10.3\% of all herbs), 15 of them ( $15.3 \%$ of all endangered species) belong to endangered.

Table 5: Occurence of herbs in forest edges

\begin{tabular}{|c|c|c|c|c|}
\hline $\begin{array}{c}\text { Fidelity to } \\
\text { forest edges }\end{array}$ & $\begin{array}{c}\text { Total No. } \\
\text { of species }\end{array}$ & $\begin{array}{c}\text { No of endangered } \\
\text { species }\end{array}$ & $\begin{array}{c}\text { No of adventive } \\
\text { species }\end{array}$ & $\begin{array}{c}\text { Fidelity to } \\
\text { forest interior }\end{array}$ \\
\hline $100 \%$ & 18 & 4 & 6 & $0,0 \%$ \\
$75-99 \%$ & 5 & 1 & 1 & $0.1-24 \%$ \\
$50-74 \%$ & 35 & 10 & 8 & $25-49 \%$ \\
$25-49 \%$ & 95 & 18 & 20 & $50-74 \%$ \\
$0.1-24 \%$ & 186 & 21 & 47 & $75-99 \%$ \\
$0 \%$ & 225 & 44 & 62 & $100 \%$ \\
\hline
\end{tabular}

\section{Identification of key problems and main management measures of floodplain forests}

Various types of floodplain forest communities occur in the alluvium of wide lowland rivers (Maděra et al. 2008) based on changing site conditions. The main ecological factors influencing species composition of floodplain communities are the height of groundwater table, the presence and duration of floods and the type of soil. The effective forest management respecting biodiversity maintenance must be based on forest type differentiation. The Umbrella species theory (Roberge, Angelstam 2004) seems to be suitable and applicable for suggestion of management principles of various floodplain forest habitats, as Machar (2008, 2010) demonstrates on examples from the Morava River basin (Czech Republic). The most usefull umbrella species of floodplain forest communities should be woody plants within the vascular plants. One umbrella woody plant species for each type of floodplain forest communities is mentioned below. 
Saliceta albae - the young developmental stages of the floodplain forest communities on fresh riparian sediment loads, in the convex bank parts of meanders. The umbrella species of this community is White Willow (Salix alba). Due to the stream channel regulations the biotopes of these communities decreased significantly.

Key problem:

- Lack of habitats due to river regulations

Main management measures:

- Regeneration of the biotopes by river revitalisation

- Rain of seeds or the water bank of seedlings can be used for rejuvenation (Maděra et al. 2009)

- Traditional way of utilization - coppicing or pollarding

- Possible to regenerate in a vegetative way

Alni glutinosae-saliceta -along gradually earthed riverside lakes, the wettest depressions in the alluvium. The umbrella species of this community is Common Alder (Alnus glutinosa).

Key problem:

- Due to the stream channel regulations the process of meandering was eliminated together with the elimination of riverine lakes. Current biotopes fill up and mature successively; with the decrease of underground water level they gradually change into drier types of floodplain forest.

Main management measures:

- Regeneration of river processes leading towards meandering of the river, however it is possible create habitats the artificial way (dig out new pools)

- Old riverine lakes can be rejuvenated by the removal of mud sediments

- Recent fragments of communities should be revitalized by the increase of the underground water level with the help of revitalization canals

- Alder trees would be necessary to regenerate mostly artificially because the current representation is in this particular area minimal

Querci roboris-fraxineta - most typical community of hardwood floodplain. The umbrella species of this community is Pedunculate Oak (Quercus robur).

Key problem:

- This hardwood community used to be the most widespread forest community of the lower part of the Morava River catchment area $-60 \%$ of the extent of the forest prior to the channel stream regulation. Following the regulations and underground water level decreas their extent dropped to a half.

Main management measures:

- The community is dependent on floods and high underground water level, it is possible to improve by artifitial channels and floods, however, river revitalisation should the best solution

- Forest managers still have to rely on clear felling method when regenerating stands with higher percentage of oak

- It is necessary to focus the research to finding a way of natural regeneration

- An effective minimal size of a clear felled area has to be set (find a compromise between ecological requirements of Pedunculate Oak for light and a good quality 
production and at the same time to minimise the negative effect of clear felling on plant diversity)

- Preservation of standards, care for mature trees

Ulmi-fraxineta carpini - the driest type of hardwood floodplain which is mainly not flooded and with the water table situated deeper than $150 \mathrm{~cm}$. The umbrella species of this community is the European White Elm (Ulmus laevis), important is also Smooth-leaved Elm (Ulmus minor). It is nowadays the most widespread biotope (approximately $60 \%$ of floodplain forests).

Key problem:

- Both Elms are strongly affected by grafiosis, their population survives only thanks to the ability of these species to create root stools.

Main management measures:

- Search for mature trees immune against grafiosis

- Seed collection of those trees followed by cultivation of planting stock

- Cultivation of resistant clones

- Not to plant elm in monocultures, always as an additional tree

- Increase the percentage of natural regeneration of communities

- $\quad$ Oak remains the main productive woody vegetation in these production stands

Ulmi-fraxineta populi - on the sand sediment loads, particularly on the natural levees skirting the water courses. The umbrella species of this community is Black Poplar (Populus nigra) but the community is also important due to the occurrence of other poplar species (P.alba, P. x canescens).

Key problem:

- These communities were the most affected by the stream channel regulation because their occurrence is connected to a relatively narrow belt of sandy gradation mound in proximity of the river. Key problem is to preserve suitable biotopes and the connected water regime. The biotope is dependent upon a regular sedimentation of sandy sediments during floods.

Main management measures:

- Rain of seeds or the water bank of seedlings can be used to regenerate poplars

- Due to the danger of introgressive hybridisation with cultivated clones of $P . x$ canadensis and genetical erosion of $P$. nigra, it is more suitable to establish sufficient numbers of suitable parental trees for inventory and to regenerate them vegetatively

\section{DISCUSSION}

Human modifications of streams and rivers have caused extensive stream channel and riparian degradation (Meixler, Bain, 2010). The most serious problem of the study area is the absence of natural hydrological regime due to the regulation of main water courses. The variety of riparian plant communities found in natural floodplains is mainly controlled by the flow regime (Poff et al. 1997), which generates physical disturbance and environmental stress on riparian vegetation, ultimately affecting its temporal and spatial dynamics (Shafroth et al. 2002). The dynamic fluvial succession by the absence of natural 
hydrological regime lead to the increase of occurence of late-serial stages (the driest types of hard-wood forests) and on the contrary, to the decrease of initial-serial stages. Gonzáles (2010) described progressive area decrease (up to 37\%) of the pioneer forest types (Populus nigra, Salix alba and Tamarix spp.) since the intensification of river regulation in the mediterranean region. In contrast, non-pioneer senescent forests have doubled their surface after river regulation was intensified. The deceleration and near elimination of the free meander dynamics of the Ebro channel represent an important loss of natural heritage. Dams, land-use changes throughout the basin, and construction of flood defences that restrict the main channel have changed behaviour of the river system which urgently needs a management plan combining both, improvement and risk reduction (Ollero, 2010).

Based on these findings Gonzáles (2010) recommended measures principally aimed at recovering some hydrogeomorphic dynamism to guarantee the self-sustainability of the floodplain forest ecosystem (González, 2010). In this sense, according to Comín et al. (2005), the most effective restoration approach in the Middle Ebro should focus on the recovery of some hydrogeomorphic dynamism (i.e., channel migration, periodic creation of new barren sites, reactivation of secondary channels, meander cut-offs, renaturalized hydroperiod, etc.) both, at the basin and the reach scale, within the current socioeconomic context (Comín and others 2005). Thus, the ideal hydrogeomorphic regime would not necessarily be the preregulation state but one 'renaturalized', which led to a selfsustainable forest structure at patch and landscape scale, guaranteed their ecological functions and provided services to society (Dufour and Piégay 2009). Ollero (2010) proposed as a solution the creation of a "Fluvial Territory". Meixler \& Bain (2010) developed the costeffective, rapid assessment tools can be used to better manage such areas by identifying the status of habitats for restoration planning and protection. Managers can use these costeffective strategy development tools to identify candidate reaches for further study and prioritize stream channel and riparian restoration actions over large regions.

High native plant diversity in riparian habitats is largely associated with natural disturbance, particularly flooding and scour by seasonal and storm related flood pulses, which creates regeneration of microsites and mediates a source of competition among species (Naiman and DeCamps 1997; Naiman et al. 1993, 2005). Frequent natural or anthropogenic disturbances, however, can also create conditions conducive to alien plant establishment (DeFerrari and Naiman 1994; Planty-Tabacchi et al. 1996; Pyle 1995; Stohlgren et al. 1998).

We found 170 adventive species in the study area, i.e. $26 \%$ of all vascular plants creating floodplain forest communities. Williams (2010) described forty alien plant species (17.8\% of the total surveyed flora) in 42 survey sites across the seven islands of the Allegheny River Islands Wilderness (ARIW, northwestern Pennsylvania). The alien flora of the ARIW included a range of species with varied ecological impact potential, distribution across plant communities, and difficulty to control. Potential control strategies for alien plant species in the ARIW must address the influence of an altered hydrologic regime as well as control protocols for specific species on the islands and surrounding river corridor.

Floodplains are considered vulnerable to the invasion of exotic species (Hood and Naiman 2000; Harris et al. 2005), due to the combined influence of intensive human exploitation, a high degree of hydrological connectivity that facilitates propagule dispersal and the high spatial and temporal heterogeneity typical for these systems. Globally, anthropogenic alterations to floodplain hydrological regimes have frequently resulted in riparian species invasions (Richardson et al. 2007). Vegetation changes are partially structured by reduced flood frequency favouring increased abundance of exotic, sexually reproducing annuals on drier sites. Sites of low flood frequency are more sensitive to future 
exotic weed invasion and will require targeted management effort. Flow restoration is predicted to benefit propagule dispersal of species adopting dual regeneration strategies, which are predominantly native species in this system (Stokes et al. 2010). The invasion by alien plant species is a major challenge to the conservation and management of riparian areas which can alter ecosystem structure and function in undesirable ways (Hood and Naiman 2000; Stohlgren et al. 1998).

The invasive species capable to get dominant are the most dangerous, as in the study area Aster lanceolatus ( ̌̌epka et al. 2009). Brewer (2010) described a similar example, a significant negative effect of species richness on invasive grass Microstegium vimineum abundance. Altogether, his results suggest that the same factors reducing biotic resistance have even greater direct positive effects on the abundance of an invasive grass and native floodplain specialists. Control of $M$. vimineum in mature floodplain forest ecosystems should be done selectively to avoid collateral damage of native floodplain specialists. On the contrary, Chiba (2010) published a different example, where the density of endemic snails of genus Ogasawarana was greater in the non-native Casuarina forest than in native vegetation, because Casuarina thick and dense litter protects them from predation by rats. The influence of non-native species on native ecosystems is not predicted easily when interspecific interactions are complex (Chiba 2010). According to the investigation of Saccone et al. (2010) Acer negundo showed both a high survival in the shade and a high growth in full light. This species could be an example of adaptive plasticity that certainly represents an advantage to give it a competitive edge over native species.

Libus et al. (2010) investigated the effect of whole-area site preparation by ploughing and of alternate field and forest crops on the understorey, soil biological activity and physical and chemical characteristics in a commercial forest. Another factor of the study was to assess the effect of the clear-cut size on forest stands. Analyzed were 20-years-old stands of pedunculate oak (Quercus robur) on alluvial sites. The authors did not find any significant differences in vascular plant biodivesity.

Natural riparian corridors are the most diverse, dynamic and complex biophysical habitats on the terrestrial part of the Earth. Riparian corridors, as interfaces between terrestrial and aquatic systems, encompass sharp environmental gradients, ecological processes and communities. Riparian corridors are an unusually diverse mosaic of landforms, communities and environments within wider landscape. They serve as a framework for understanding of the organisation, diversity and dynamics of communities associated with fluvial ecosystems. Riparian corridors possess an unusually diverse array of species and environmental processes and they should play an essential role in water and landscape planning, in the restoration of aquatic systems, and in catalyzing institutional and societal cooperation for these efforts (Naiman 1993). The establishment of forest edges in the Elbe floodplain and woody plants growth at different conditions was researched by Osterloh et al. (2010), the suitable shape and woody species composition of forest edges are very important conditions to fulfill biocorridor function (Maděra et al. 2004). But the role of riparian corridors should be ambivalent because dispersion both, native and adventive species, as Matějček (2007) mentioned. Starting in the 1970s, forestry has been undergoing a fundamental change due to public pressure for changes in forest management practices, triggered by changing demands for ecosystem services (Kimmins, 2002). Management of floodplain forests in changing environmental conditions, including global climatological changes (Moradkhani, 2010), is affected by considerable uncertainty. Therefore, an adaptive management is suitable approach. According to Foster et al. (2010) the biodiversity conservation is a necessary part of an adaptive management framework, that will help forest owners and managers implement the sustainable forest management. The 
proposed concept challenges various domains. Research has to improve its understanding of process interactions across space-time scales, characterized by dose-response models which are essential to understand the robustness (resilience) of a system. Higher education related to ecosystem management should re-focus on scientific competences to the analysis of complex adaptive systems, and the use of control theory to continuously improve policies and practices for ecosystem management. Practitioners in field have to become convinced that the goal of ecosystem management is a "moving target", consisting of a portfolio of ecosystem goods and services. They have to internalize the principle of "rule discovery" as a systematic learning process to improve management practices and by looking for "biodiversity in our minds". It is expected that discussions will be triggered among scholars and practitioners, leading to a set of principles for resource use that consider both, complexity and dynamics of ecosystems (Heinimann, 2010). Adaptive management is a concept that has been increasingly adopted in natural resource management (Holling 1978; Walters 1986). It describes the integration of knowledge gained through research, monitoring and management to evaluate and progressively improve management practices, while spreading risks of failure (Duncan \& Wintle 2008). A key feature of the approach is the explicit recognition of uncertainty about the outcome of management actions (Duncan \& Wintle 2008). In an adaptive approach, alternative management strategies are designed and implemented as comparative experiments to evaluate their efficacy and relative merits in achieving explicite conservation goals. Management actions which are informative, reversible and robust to uncertainty are favoured, thus minimising risk (Lindenmayer \& Burgman 2005). Regular, ongoing monitoring is crucial to the adaptive approach, providing performance evaluation of current management strategies and triggering their review when a disturbance or change in a system is detected (Lindenmayer \& Burgman 2005; Duncan \& Wintle 2008). Hence, adaptive management is widely regarded as an effective and powerful framework to support successful management of natural resources (Johnson 1999; Lindenmayer \& Burgman 2005). Building adaptive capacity of interlinked social and ecological systems is assumed to improve implementation of sustainable forest management policies. One mechanism is collaborative learning by continuous evaluation, communication, and transdisciplinary knowledge production. The Model Forest concept, developed in Canada, is intended to encourage all dimensions of sustainable development through collaboration among stakeholders of forest resources in a geographical area. Because the Model Forest approach encompasses both, social and ecological systems, it can be seen as a process aimed to improvement of adaptive capacity to deal with uncertainty and change (Elbakidze et al. 2010). The Model Forest seems to be one of the solutions to most conflicts of interest of all stakeholders in the study area.

\section{CONCLUSIONS}

- The places of interest (centers of biodiversity, locality of endangered species) were identified in the study area

- All developmental stages of forest stands from clearings to mature stands are important to biodiversity maintenance

- Key measure should be to repair hydrological conditions of river and the entire alluvium. The meandering river is necessary for creation of habitats of soft-wood floodplain forest communities, the floods are necessary for aplication of dynamic management instead of static protection in situ 
- The problem of adventive plants, especialy invasive neophytes is extensive and difficult to resolve

- It is suitable for adaptation management assesment to use the umbrella species theory according to environmental conditions

- Model Forest approach is recomended in the study area

\section{ACKNOWLEDGEMENTS}

The article was published thank to support of National Academy for Agriculture Research (project reg. No. QI92A031), Internal Grant Agency of Faculty of Forestry and Wood Technology Mendel University in Brno (project reg. No. 12/2010) and Ministry of Education of the Czech Republic (project LANDTEAM, reg. No.CZ.1.07/2.3.00/20.0004 and faculty research program reg. No. MSM 215648902).

\section{REFERENCES}

Anderson, M.G., Ferree, Ch.E., Olivero, P.A. \& Zhao, F. (2010). Assessing Floodplain Forests: Using Flow Modeling and Remote Sensing to Determine the Best Places for Conservation. Natural Areas Journal, 30(1):39-52.

Brewer, J.S. (2010). A Potential Conflict between Preserving Regional Plant Diversity and Biotic Resistance to an Invasive Grass, Microstegium vimineum. Natural Areas Journal, 30(3):279-293

Comín, FA., Menéndez, M., Pedrocchi, C., Moreno, S., Sorando, R., Cabezas, A., García, M., Rosas, V., Moreno, D., González, E., Gallardo, B., Herrera, J.A. \& Ciancarelli, C. (2005). Wetland restoration: integrating scientific-technical, economic, and social perspectives. Ecological Restoration 23(3):182-186

De Ferrari, C. M. \& Naiman, R. J. (1994). A multi-scale assessment of the occurrence of exotic plants on the Olympic Peninsula, Washington. J. Veg. Sci., 5: 247-258.

Dufour, S., Piégay, H. (2009). From the myth of a lost paradise to targeted river restoration: forget natural references and focus on human benefits. River Research and Applications 25(5):568-581

Duncan, D. H., Wintle, B. A. (2008). Towards adaptive management of native vegetation in regional landscapes. In: Pettit, C., Bishop, I., Cartwright, W., Duncan, D., Lowell, K. \& Pullar, D. (Eds.): Landscape Analysis and Visualisation. Spatial Models for Natural Resource Management and Planning, (pp. 159-182). Springer-Verlag GmbH, Berlin, Germany

Dynesius, M., Nilsson, C. (1994). Fragmentation and flow regulation of river systems in the northern third of the world. Science 266:753-761.

Elbakidze, M., Angelstam, P.K., Sandstrom, C. \& Axelsson, R. (2010). Multi-stakeholder collaboration in russian and swedish model forest initiatives: Adaptive governance toward sustainable forest management? Ecology and Society. Volume 15, Issue 2, pp.13.

Foster, B.C., Wang, D., Keeton, W.S. \& Ashton, M.S. (2010). Implementing sustainable forest management using six concepts in an adaptive management framework. Journal of Sustainable Forestry, Volume 29, Issue 1, 79-108 
González, E., González-Sanchis, M., Cabezas, A., Comín, F.A. \& Muller, E. (2010). Recent Changes in the Riparian Forest of a Large Regulated Mediterranean River: Implications for Management. Environmental Management Vol. 45:669-681

Harris, M.B., Tomas, W., Mourao, G., Da Silva, C.J., Guimaraes, E., Sonoda, F. \& Fachim, E. (2005). Safeguarding the Patanal wetlands: threats and conservation initiatives. Conserv.Biol 19:714-720

Heinimann, H.F. (2010). A concept in adaptive ecosystem management. An engineering perspective. Forest Ecology and Management 259: 848-856

Holling, C. S. (1978). Adaptive Environmental Management and Assessment. John Wiley and Sons, Chichester, UK

Holub, J., Procházka, F. (2000). Red List of vascular plants of the Czech Republic. Preslia, Praha, 72: 187-230.

Hood, G.W., Naiman, R.J. (2000). Vulnerability of riparian zones to invasion by exotic vascular plant species. Plant Ecol., 148:105-114

Chiba, S. (2010). Invasive non native species provision of refugia for endangered native species. Conservation Biology, Vol. 24, Issue 4, 1141-1147 pp.

Johnson, B. L. (1999). The role of adaptive management as an operational approach for resource management agencies. Conservation Ecology, 3, 8. Available from URL: http://www. consecol.org/vol3/iss2/art8/.

Jones, K.B., Slonecker, E.T., Nash, M.S., Neale, A.C., Wade, T.G. \& Hamann, S. (2010). Riparian habitat changes across the continental United States (1972-2003) and potential implications for sustaining ecosystem services. Landscape Ecol, 25:1261-1275

Kimmins, J.P. (2002). Future shock in forestry. Where have we come from; where are we going; is there a "right way"' to manage forests? Lessons from Thoreau, Leopold, Botkin and Nature. The Forestry Chronicle, 78, 263-271.

Klimo, E., Hager, H. (2000). The floodplain forests in Europe. EFI, Leiden, Boston, Köln, Brill., 268 pp.

Libus, J., Mauer, O. \& Vavř́íček, D. (2010). Soil preparation by ploughing in the floodplain forest and its influence on vegetation and primary soil characteristics. Journal of Forest Science, Vol. 56, Issue 4, 183-194 pp.

Lindenmayer, D., Burgman, M. (2005). Practical Conservation Biology, CSIRO Publishing, Collingwood, Vic.

Maděra, P., Packová, P. (2004). Primary succession of white willow communities in the supraregional biocorridor in the Middle water reservoir of Nové Mlýny. Ekológia (Bratislava), Vol.23, Supplement 1/2004: 191-204 pp.

Maděra, P., Svobodová, I. \& Packová, P. (2009). Oecesis of White Willow Communities in the nature reserve Věstonická nádrž reservoir. Ekológia (Bratislava), 28 (1): 7-21 pp.

Maděra, P.; Vukelic, J., Buček, A. \& Baričevic, D. (2008). Floodplain forest plant communities. In. Klimo, E. et al. (Eds.): Floodplain forests of the temperate zone of Europe. (102-159 pp.) Lesnická práce, Kostelec nad Černými lesy

Machar, I. (2008). A proposed target state for a floodplain forest ecosystem within an ecological network, with reference to the ecological requirements of an umbrella bird species: the common kingfisher. Journal of Lanscape Ecology, Vol.1, No.2: 80-98. 
Machar, I. (2010). Biodiversity and target management of floodplain forests in the Morava River basin. Palacky Univesity in Olomouc, 227 pp.

Matějček, T. (2007).Výskyt invazních neofytů v břehové vegetaci středního Labe. In. Měkotová, J., Štěrba, O.: Řični krajina 5. (189-196 pp.) Sborník př́íspěvků z konference, Olomouc

Meixler, M.S., Bain, M.B. (2010). Landscape scale assessment of stream channel and riparian habitat restoration needs. Landscape Ecol Eng 6:235-245

Moradkhani, H., Baird, R.G. \& Wherry S.A. (2010). Assessment of climate change impact on floodplain and hydrologic ecotones. Journal of Hydrology 395: 264-278

Naiman, R. J., Decamps, H. (1997). The ecology of interfaces: Riparian zones. Ann. Rev. Ecol, Syst. 28: 621-658.

Naiman, R. J ., Decamps, H. \& Mc Clain, M.E. (2005). Riparia: Ecology, Conservation, and Management of Streamside Communities. Elsevier Academic Press, New York

Naiman, R.J., Decamps, H. \& Pollock, M. (1993). The role of riparian corridors in maintaining regional biodiversity. Ecol Appl., 3:209-212

Nožička, J. (1956). Z historie jihomoravských luhů. Předběžná studie. Práce výzkumných ústavů lesnických ČSR, Vol. 10, p. 169-199.

Ollero, A. (2010). Channel changes and floodplain management in the meandering middle Ebro River, Spain. Geomorphology 117 (2010) 247-260

Osterloh, S., Felinks, B., Kreibich, M. \& Glaeser, J. (2010). Establishment of Forest Edges in the Floodplain of the River Elbe. Naturschutz und Landschaftsplanung, Vol. 42, Issue 2.

Planty-Tabacchi, A., Tabacchi, E., Naiman, R. J., De Ferrari, C. M. \& Decamps, H. (1996). Invasibility of species-rich communities in riparian zones. Conservation Biol., 10: 598-607.

Penka, M., Vyskot, M., Klimo, E. \& Vašíček, F. (1991). Floodplain forest ecosystem 2. Academia (Elsevier), Praha, 632 pp.

Poff, N.L., Allan, J.D., Bain, M.B., Karr ,J.R., Prestegaard, K.L., Richter, B.D., Sparks, R.E. \& Stromberg, J.C (1997). The natural flow regime. A paradigm for river conservation and restoration. Bioscience, 47:769-784.

Pyle, L. L. (1995). Effects of disturbance on herbaceous exotic plant species on the floodplain of the Potomac River. Amer. Midl. Naturalist,134: 244-253.

Pyšek, P., Sádlo, J. \& Mandák, B. (2002). Catalogue of alien plants of the Czech Republic. Preslia, Praha, 74: 97-186.

Richardson, D., Holmes, P.M., Elser, K.J., Galatowitsch, S.M., Stromberg, J.C., Kirkman, S.P., Pyšek, P. \& Hobbs, R.J. (2007). Riparian vegetation: degradation, alien plant invasions, and restoration prospects. Divers Distrib 13:126-139

Roberge, J.M., Angelstam, P. (2004). Usefulness of the Umbrella Species Concept as a Conservation Tool. Conservation Biology, Vol. 18, No. 1, 76-85

Řepka, R., Maděra, P. (2009). Diverzita vyššich cévnatých rostlin lužního lesa ve vztahu $k$ jeho věku. Zprávy České Botanické Společnosti, Materiály. sv. 44, č. 24, s. 101-110.

Saccone, P., Brun, J.J. \& Michalet, R. (2010). Challenging growth-survival trade-off: A key for acer negundo invasion in European floodplains? Canadian Journal of Forest Research, Vol. 40, Issue 10, 1879-1886 pp.

Shafroth, P.B, Stromberg, J.C. \& Patten, D.T. (2002). Riparian vegetation response to altered disturbance and stress regimes. Ecological Applications 12(1):107-123 
Stohlgren, T. J., Bull, K. A., Otsuki, Y., Villa, C. A. \& Lee, M. (1998). Riparian zones are havens for exotic plant species in the central grasslands. Pl. Ecol., 138: 113-125.

Stokes, K., Ward, K. \& Colloff, M. (2010). Alterations in flood frequency increase exotic and native species richness of understorey vegetation in a temperate floodplain eucalypt forest. Plant Ecol. 211:219-233

Tockner, K., Schiemer, F. (1997). Ecological aspects of the restoration strategy for a riverfloodplain system on the Danube River in Austria. Global Ecology and Biogeography Letters 6:321-329.

Trowbridge, W.B. (2007). The role of stochasticity and priority effects in floodplain restoration. Ecological applications 17:1312-1324.

Verry, E. S., Hornbeck, J. W. \& Dolloff, C. A. (2000). Riparian Management in Forests of the Continental Eastern United States. Lewis Publishers, New York,

Vicherek, J. (2000). Flóra a vegetace na soutoku Moravy a Dyje. Masarykova univerzita v Brně, Brno, 368 pp.

Walters, C. J. (1986). Adaptive Management of Renewable Resources. MacMillan, New York,

Wenger, E.L., Zinke, A. \& Gutzweiler, K.A. (1990). Present situation of the European floodplain forests. Forest Ecology and Management, 33-34, p. 5-12.

Williams, Ch.E. (2010). Survey of the alien flora of the Allegheny river island wilderness, Pennsylvania. Rhodora, Vol. 112, No. 950, pp. 142-155 